Insight Bacteriology 2 (1): 3-9, 2013

ISSN 2044-8961 / DOI: 10.5567/BACTERIOL-IK.2013.3.9

(C) 2013 Insight Knowledge, UK

\title{
Effect of Carbon and Nitrogen Sources of the Medium used to Grow Biocontrol Strain UTPF61 of Pseudomonas fluorescens on its Protective Activity Against Sclerotinia Wilt of Sunflower and its Survival During and after the Formulation Process
}

\author{
${ }^{1}$ Fereshteh Heidari-Tajabadi, ${ }^{1}$ Masoud Ahmadzadeh, \\ ${ }^{2}$ Vahid Fallahzadeh-Mamaghani and ${ }^{1}$ Asma Moeinzadeh \\ ${ }^{1}$ Laboratory of Biological Control of Plant Disease, Department of Plant Protection, \\ College of Agriculture, University of Tehran, Karaj, Iran \\ ${ }^{2}$ Department of Agronomy and Plant Breeding, Faculty of Agricultural Science and Engineering, \\ College of Agriculture and Natural Resources, University of Tehran, Karaj, Iran
}

Abstract: Background: Sclerotinia wilt caused by Sclerotinia sclerotionum, is a devastating disease of sunflower worldwide. One promising area of disease management for resource-poor farmers that emerged in recent years in developing countries is the potential of biological control. Material and methods: Pseudomonas fluorescens strain UTPF61 is an effective biocontrol agent for sclerotinia wilt disease. One major constraint in large-scale field evaluation of biocontrol agents of sclerotinia wilt is their availability in large quantities. Fermentation is important in order to simplify production of biocontrol agents. But the large scale production of biocontrol agent is expensive because of the high cost of the medium. Then this problem is solved with the use of inexpensive agriculturalbyproducts such as molasses and corn steep. Results: This research investigated the effect of some combinations of carbon and nitrogen sources during fermentation of Pseudomonas fluorescens UTPF61 on its growth in flask and fermentor and its subsequent antagonistic activity in vitro and protective activity in plant. Its survival during the formulation process and shelf life over a period of 150 days was investigated. Rapid growth in flask was observed in medium containing Molasses +yeast extract but medium containing Molasses +2 -ammonium hydrogen phosphate had the best effect on the antagonistic efficacy, biocontrol activity, PGPR and survival of bacteria.

Key words: Antagonistic efficiency, antifungal activity, biological control, carbon and nitrogen sources, fermentation formulation, fluorescent pseudomonads, Sclerotinia sclerotionum

INTRODUCTION

Sclerotinia sclerotionum is a plant pathogenic fungus that causes destructive diseases of numerous succulent plants (Agrios, 2005). Sunflower (Helianthus annus L.) is vulnerable to some pathogens especially the fungus $S$. scterotiorum.

Biological control is an important component of integrated pest management (Zhang et al., 2005). Work on biological control of sclerotinia wilt has intensified (Duffy and Defago, 1999), because no progress in breeding for resistance to sclerotinia wilt in sunflower has been obtained and no effective chemical control of this disease is known (Expert and Digat, 1995). Some strains of
$P$. fluorescens were reported to be biocontrol agents of various soil born fungi (Weller, 1988; Defago et al., 1990; Expert and Digat, 1995). In spite of these advantages there is little published on commercial production of these agents.

For commercial application, an economical, largescale mass production method must be developed for $P$. fluorescens and other biocontrol agents. Commercialization of Pseudomonas inocula requires the development of appropriate liquid-culture technology for mass production (Slininger and Sheawilbur, 1995). In this kind of fermentation our goal is to obtain a large amount of microbial agent with high efficacy, high resistance to the drying process involved in formulation and a long

Corresponding Author: Fereshteh Heidari-Tajabadi, Laboratory of Biological Control of Plant Disease, Department of Plant Protection, College of Agriculture, University of Tehran, Karaj, Iran Tel: 0098-9133910137 Fax: 0098-391-8229004 
shelf life. There are some reports that medium components (carbon and nitrogen sources and their ratios, mineral factors, etc.) and conditions ( $\mathrm{pH}$, temperature and oxygen transfer) used to grow biocontrol agents, influence their subsequent properties. Fermentation media for production of biocontrol agent should consist of substrates necessary for the growth of microorganism, primarily the carbon, nitrogen and phosphorus sources (Ali et al., 2002). Use of commercial products or by-products from food industries, such as molasses, corn steep liquor, malt extract, yeast extract and etc has tended to meet most of the above criteria for production media because they are cheap substrates (Costa et al., 2001). Molasses was employed as the basal fermentation media in the stirred fermentor under the submerged fermentation conditions (Ali et al., 2002). The importance of inexpensive and readily available media components for commercial products has long been recognizing (Adams et al., 2002).

The aims of this study were to find the nitrogen and carbon sources that provide maximum biomass production of Pseudomonas fluorescens strain UTPF61, improving the biocontrol potential against the Sclerotinia sclerotionum and its viability during the formulation process.

\section{MATERIALS AND METHODS}

Biocontrol strain: P. fluorescen UTPF 61 was selected out of 40 strains of fluorescent pseudomonads on the basis of dual culture assays, growth promotion activity on sunflower and production of $\mathrm{HCN}$ and protease (Heidary, 2008; Moeinzadeh etal., 2010). This strain was originally isolated from the hizosphere of rice. Stock cultures were prepared for storage at $-80^{\circ} \mathrm{C}$ in $1.5 \mathrm{~mL}$ vials by mixing equal volumes of $50 \%$ glycerol and $24 \mathrm{~h}$ culture broth (from single colony inoculum, $25 \mathrm{~mL}$ Luria Bertani medium, $100 \mathrm{~mL}$ flask, $130 \mathrm{rmm}$ ).

Flask culture studies: The media used in this study were a semi-defined media $\left(M_{1}, M_{2}\right.$ and $\left.M_{3}\right)$, each medium containing in grams per liter: $\mathrm{M}_{1}: \mathrm{K}_{2} \mathrm{HPO}_{4}$ $\left(0.98 \mathrm{~g} \mathrm{~L}^{-1}\right)+\mathrm{MgSO}_{4}\left(0.4 \mathrm{~g} \mathrm{~L}^{-1}\right)+\mathrm{CaCO}_{3}\left(0.4 \mathrm{~g} \mathrm{~L}^{-1}\right)$ +molasses $\left(10 \mathrm{~g} \mathrm{~L}^{-1}\right)+$ corn steep $\left(4 \mathrm{~g} \mathrm{~L}^{-1}\right) ; \mathrm{M}_{2}: \mathrm{K}_{2} \mathrm{HPO}_{4}$ $\left(0.98 \mathrm{~g} \mathrm{~L}^{-1}\right)+\mathrm{MgSO}_{4}\left(0.4 \mathrm{~g} \mathrm{~L}^{-1}\right)+\mathrm{CaCO}_{3}\left(0.4 \mathrm{~g} \mathrm{~L}^{-1}\right)$ + starch $\left(10 \mathrm{~g} \mathrm{~L}^{-1}\right)+$ corn steep $\left(4 \mathrm{~g} \mathrm{~L} \mathrm{~L}^{-1}\right), \mathrm{M}_{3}: \mathrm{K}_{2} \mathrm{HPO}_{4}$ $\left(0.98 \mathrm{~g} \mathrm{~L}^{-1}\right)+\mathrm{MgSO}_{4}\left(0.4 \mathrm{~g} \mathrm{~L}^{-1}\right)+\mathrm{CaCO}_{3}\left(0.4 \mathrm{~g} \mathrm{~L}^{-1}\right)+$ malt extract $\left(10 \mathrm{~g} \mathrm{~L}^{-1}\right)+$ corn steep $\left(4 \mathrm{~g} \mathrm{~L}^{-1}\right)$. Then in order to investigate the effect of different additional nitrogen sources, different nitrogen sources (tested at $2 \mathrm{~g} \mathrm{~L}^{-1}$ ) including 2-ammonium hydrogen phosphate, ammonium sulfate and peptone added to $M_{1}, M_{2}$ and $M_{3}$ media separately. Also urea and yeast extract as nitrogen sources and malt extract just added to $M_{1}$ medium separately $\left(2 \mathrm{~g} \mathrm{~L}^{-1}\right)$. This medium was autoclaved for $15 \mathrm{~min}$ at $121^{\circ} \mathrm{C}$. Flask cultures were inoculated using $1 \mathrm{~mL}$ of a $24 \mathrm{hNA}$ culture of UTPF 61 adjusted to $10^{6} \mathrm{CFU} \mathrm{mL}^{-1}$ in sterile distilled water. Cultures were incubated for $48 \mathrm{~h}$ at $120 \mathrm{rpm}$ and $25^{\circ} \mathrm{C}$ in a rotary shaker incubator, thereafter cell density was determined by cell density standard curve (at $600 \mathrm{~nm}$ ) and cultures were used for formulation, dual culture assays and greenhouse studies.

Fermentor studies: A fermentor experiment was designed to mimic the industrial fermentation process in which typically there is stepwise scale-up of batch size (Lam et al., 1994; Schroth et al., 1984). For preparation of seed culture, $50 \mathrm{~mL}$ of TSB (Tryptic Soy Broth) medium were inoculated with $1 \mathrm{~mL}$ of fresh culture of bacterial suspension with $10^{6} \mathrm{CFU} \mathrm{mL}^{-1}$. Then medium incubated for $24 \mathrm{hin}$ a rotary shaker at $26^{\circ} \mathrm{C}$ and $120 \mathrm{rpm}$. One milliliter of this culture was transferred to $100 \mathrm{~mL}$ of fresh medium in a $250 \mathrm{~mL}$ Erlenmeyer flask as a seed culture. This medium was incubated at $25^{\circ} \mathrm{C}$ under agitation (120 rpm). Finally after $6 \mathrm{~h}$ this broth with approximately $10^{6}$ cells $\mathrm{mL}^{-1}$ in $\log$ phase was transferred to a fermentor under sterile conditions. Before transfer optical density of seed culture were estimated directly by spectrophotometer at $600 \mathrm{~nm}$ (PG instruments $\mathrm{T} 70+$, England). A 7.5 liter bench-top experimental fermentor (BioFlo 110, New Brunswick Scientific, USA) with a 21 yorking volume was operated in batch culture mode. Temperature was kept at $26^{\circ} \mathrm{C}$ and the initial $\mathrm{pH}$ was adjusted to 7 . The $\mathrm{pH}$ was monitored by a $\mathrm{pH}$ probe (Metter Toledo 405-DPAS-SC-k85/325) and Dissolved Oxygen (DO) with a polarographic DO electrode (Ingold Inpro 6800 series ), The DO probe was calibrated at $0 \%$, (obtained by briefly disconnecting the cable) and at $100 \%$, (obtained using $800 \mathrm{rpm}$ agitation and $51 \mathrm{~min}^{-1}$ [1 vvm] airflow). An agitation cascade was selected in the controller to maintain $\mathrm{DO}$ at $25-30 \%$ saturation via automatic adjustment of the agitation speed. To avoid formation of foam, castor oil was added in automatically mode. The volume of seed cultures were $2 \%(\mathrm{v} / \mathrm{v})$ of fermentor medium. Cells of P. fluorescens UTPF61 in different stages of growth (15 and $25 \mathrm{~h}$ after inoculation) were harvested in $40 \mathrm{~mL}$ aliquots from the fermentor and each aliquot was used for dual culture assays and greenhouse studies. All fermentor experiments were conducted in triplicate.

In vitro antagonistic activity: The in vitro inhibition of mycelial growth of S. sclerotionum by the strain UTPF61 was tested using the dual culture technique as described by Keel et al. (1996). Three $10 \mu \mathrm{L}$ drops from different cultivation runs were equidistantly placed on the 
margins of Potato Dextrose Agar (PDA) plates and incubated at $25^{\circ} \mathrm{C}$ for $24 \mathrm{~h}$. Thereafter a $7 \mathrm{~mm}$ agar disc from fresh PDA cultures of $S$. sclerotionum was placed at the centre of the PDA plate and incubated at $20^{\circ} \mathrm{C}$ for five days. Inhibition of fungal growth was assessed 5 days later by measuring the size of the inhibition zone (in $\mathrm{mm}$ ).

Formulation and air-drying: Medium containing $9 \times 10^{8}$ CFU mL ${ }^{-1}$ was used for the preparation of a talc-based formulation. To $400 \mathrm{~mL}$ of bacterial suspension, $1 \mathrm{~kg}$ of purified talc powder (sterilized at $120^{\circ} \mathrm{C}$ for $15 \mathrm{~h}$ ), calcium carbonate $15 \mathrm{~g}$ (to adjust the $\mathrm{pH}$ to neutral) and carboxymethyl cellulose (CMC) $10 \mathrm{~g}$ (adhesive) were mixed under sterile conditions, as described by Vidhyasekaran and Muthamilan (1995). The product was air dried at $15^{\circ} \mathrm{C}$ under sterile conditions until moisture content reached $15-20 \%$. After a further $12 \mathrm{~h}$ this product was powdered in a grinder for $1 \mathrm{~min}$ and maintained at two temperatures 25 and $4^{\circ} \mathrm{C}$ in vials. One gram of this formulation was used for viability assays by serial dilution method at determined intervals.

Greenhouse studies: Bacteria that harvested from different cultivation media were tested for their protec activity against $S$. sclerotionum and their ability of plant growth promotion. Experiments were performed in plastic pots (diameter, $7.5 \mathrm{~cm}$; depth, 8) containing sterilized soil (sand 3 , clay 1 , humus 1 ). Surface-sterilized ( $5 \%$ sodium hypochlorite for $3 \mathrm{~min}$ and rinsed five times with sterile distilled water) and post germinated seeds of sunflower bacterized by soaking in bacterial suspension $\left(1 \times 10^{8} \mathrm{CFU} \mathrm{mL}^{-1}\right)$ for 30 min with a moderate shaking. Bacterial suspensions prepared by resuspending the pelleted bacteria (by centrifuging at $5000 \times \mathrm{xg}$ for $10 \mathrm{~min}$ ) from different media by $1 \%$ Carboxymethyl cellulose (CMC) slution. Control seeds were shaken only in $1 \%$ CMC solution for half an hour. To prepare inoculum of S. sclerotiorum for greenhouse studies (protective activity test), millet seeds were sterilized $\left(121^{\circ} \mathrm{C}, 20 \mathrm{~min}\right.$, twice), inoeulated with mycelial plugs and incubated at $20^{\circ} \mathrm{C}$ for 20 days. For protective activity test, $1 \mathrm{~g}$ of prepared inoculum was mixed into the upper part of sterile soil, prior to seed planting. For the control treatments, sterile millet seed was mixed into the soil at the same rate. For PGPR test bacterized seeds (as described above) were planted in sterile perlite and irrigated by nutrient solution. Plants were grown in the greenhouse under day and night temperatures of $25 / 18^{\circ} \mathrm{C}$ with a $14 \mathrm{~h}$ photoperiod and $75 \%$ relative humidity. Pots were fully randomized in different places and treatments were as follows: uninoculated seeds (without bacteria $=$ control treatment) with or without fungus and inoculated seed (with bacteria) with or without fungus. Treatments were replicated three times. In antagonistic tests, 30 days after planting, the percentage of healthy plants was determined according to the procedure described by Expert and Digat (1995) and in PGPR test, the length of root and stem, the wet and dry weight of root and stem was calculated after 30 days after sowing.

Statistical analysis: Data were analyzed for significance by analysis of variance, followed by Duncan's multiple range test $(\mathrm{p}<0.05)$, with the SAS general linear model procedure (SAS Institute, Cary, NC). Normal distribution and homogeneity of variances were checked beforehand. Complete Randomized Design (CRD) was used in all experiments and each treatment was replicated three times

Effect of different carbon and nitrogen source on growth of UTPF61: Bacteria originating from flask culture in medium containing $\mathrm{M}_{1}+$ yeast extract were more effective on growth of UTPF61 as its optical density was 1.74 after $48 \mathrm{~h}$. Moreover $\mathrm{M}_{1}+$ peptone and $\mathrm{M}_{1}+2$-ammonium hydrogen phosphate media had a good effect on bacterial growth (Table 1). Bacteria originating from fermentor in medium containing $\mathrm{M}_{1}+2$-ammonium hydrogen phosphate were more effective on growth of cells as its OD was 2.89 at the end of the cultivation. The effect of other media including $\mathrm{M}_{1}+$ urea and $\mathrm{M}_{1}+$ peptone on growth of bacterium was not significantly different in both of the times (Table 2).

Table 1: Effect of some carbon and nitrogen sources in flask culture on the rate of growth and antagonistic efficacy of $P$. fluorescens strain UTPF 61 in $25^{\circ} \mathrm{C}$ and after $48 \mathrm{~h}$

\begin{tabular}{|c|c|c|}
\hline Media & $\log _{10}$ Cells $\left(\mathrm{mL}^{-1}\right)$ & Inhibition zone $(\mathrm{mm})^{\mathrm{a}}$ \\
\hline $\mathrm{M}_{1}$ & $13.266^{\text {abcd *** }}$ & $6.67^{\mathrm{e}}$ \\
\hline $\mathrm{M}_{1}+$ peptone & $14.592^{\mathrm{ab}}$ & $12.33^{\mathrm{a}}$ \\
\hline $\begin{array}{l}\mathrm{M}_{1}+2 \text {-ammonium hy drogen } \\
\text { phosphate }\end{array}$ & $13.812^{\mathrm{abc}}$ & $12.33^{\mathrm{a}}$ \\
\hline $\mathrm{M}_{1}+$ ammonium sulphate & $13.032^{\text {abcde }}$ & $6.33 \mathrm{e}^{\mathrm{f}}$ \\
\hline $\mathrm{M}_{1}+$ urea & $12.954^{\text {bcde }}$ & $9.67^{c}$ \\
\hline $\mathrm{M}_{1}+$ yeast extract & $15.372^{\mathrm{a}}$ & $6.67^{e}$ \\
\hline $\mathrm{M}_{1}+$ malt extract & $11.784^{\text {cdef }}$ & $0.11^{\mathrm{b}}$ \\
\hline $\mathrm{M}_{2}$ & $11.706^{\text {cdef }}$ & $6.33^{\text {ef }}$ \\
\hline $\mathrm{M}_{2}+$ peptone & $11.55^{\text {cdef }}$ & $9.67^{c}$ \\
\hline $\begin{array}{l}\mathrm{M}_{2}+2 \text {-ammonium hy drogen } \\
\text { phosphate }\end{array}$ & $11.16^{\text {def }}$ & $8.17^{\mathrm{d}}$ \\
\hline $\mathrm{M}_{2}+$ ammonium sulphate & $12.408^{\text {bcde }}$ & $8.33^{\mathrm{d}}$ \\
\hline $\mathrm{M}_{3}$ & $10.614^{\mathrm{ef}}$ & $5.5^{\mathrm{fgh}}$ \\
\hline $\mathrm{M}_{3}+$ peptone & $10.848^{\text {def }}$ & $5.33^{\mathrm{gh}}$ \\
\hline $\begin{array}{l}\mathrm{M}_{3}+2 \text {-ammonium hy drogen } \\
\text { phosphate }\end{array}$ & $9.834^{\mathrm{f}}$ & $0.5^{\mathrm{h}}$ \\
\hline $\mathrm{M}_{3}+$ ammonium sulphate & $11.16^{\text {def }}$ & $0.6^{\mathrm{efg}}$ \\
\hline
\end{tabular}

aidth of the zone of inhibition was measured from the edge of the fungal colony to the edge of the bacterial colony, statistical significance was judged at the $\mathrm{p}<0.01,{ }^{* * *} \mathrm{OD} 600$ 
Table 2: Effect of some culture media on the rate of growth and antagonistic efficacy of $P$. fluorescens strain UTPF61 grown on fermentor in $26^{\circ} \mathrm{C}$ and with two different times 15 and $25 \mathrm{~h}$ after incubation time

\begin{tabular}{|c|c|c|}
\hline Media & $\log _{10}$ cells $\left(\mathrm{mL}^{-1}\right)$ & Inhibition zone $(\mathrm{mm})^{\mathrm{a}}$ \\
\hline $\mathrm{M}_{1}+$ peptone (after $15 \mathrm{~h}$ ) & $17.4312^{\text {a*** }}$ & $12.67^{\mathrm{bc}}$ \\
\hline $\mathrm{M}_{1}+$ peptone (after $25 \mathrm{~h}$ ) & $20.442^{b}$ & $11 b^{c}$ \\
\hline $\begin{array}{l}\mathrm{M}_{1}+2 \text {-ammonium hy drogen } \\
\text { phosphate (after } 15 \mathrm{~h} \text { ) }\end{array}$ & $24.342^{\mathrm{a}}$ & $12.3^{\mathrm{a}}$ \\
\hline $\begin{array}{l}\mathrm{M}_{1}++2 \text {-ammonium } \\
\text { hydrogen phosphate } \\
\text { (after } 25 \mathrm{~h} \text { ) }\end{array}$ & $24.108^{a}$ & $12.3^{\mathrm{a}}$ \\
\hline $\mathrm{M}_{1}+$ urea (after $15 \mathrm{~h}$ ) & $21.144^{b}$ & $10.33^{c}$ \\
\hline $\mathrm{M}_{1}+$ urea (after $25 \mathrm{~h}$ ) & $19.74^{b}$ & $10.33^{c}$ \\
\hline
\end{tabular}

${ }^{a}$ Width of the zone of inhibition was measured from the edge of the fungal colony to the edge of the bacterial colony, statistical significance was judged at the $p<0.01,{ }^{* * *} \mathrm{OD} 600$

In vitro antagonistic test: Bacteria originating from flask culture in media containing $\mathrm{M}_{1}+$ peptone or $\mathrm{M}_{1}+2$ ammonium hydrogen phosphate showed protective activity (12.33 mm inhibition zone on the medium used) against $S$. sclerotiorum (Table 1). Bacteria originating from fermentor in medium containing $\mathrm{M}_{1}+2$-ammonium hydrogen phosphate, showed protective activity (12.33 $\mathrm{mm}$ inhibition zone on the medium used) aganst S. sclerotionum in both of the times 15 and $25 \mathrm{~h}$ after inoculation and the effect of this medium on the protective activity of UTPF61 was significantly more than those of other media (Table 2).

Greenhouse experimen ammonium hydrogen phosphate or $\mathrm{M}_{2}+2$-ammonium hydrogen phosphate shoved a strong inhibition against $S$. scletoriorum, yielding $84.47 \%$ healthy plants after 30 days (Fig. 1). Investigation of plant growth promotion test in greenhouse trials showed that cells of UTPF61 grown in $\mathrm{M}_{1}+2$-ammonium hydrogen phosphate were more effective in increasing the root and stems length and dry and wet weight of plants. Also its effect was significantly different with control treatment. Length of roots in all of the treatments was same but they were significantly different with control treatment (Table 3 ).

Bacteria originating from fermentor in media containing $\mathrm{M}_{1}+2$-ammonium hydrogen phosphate and $\mathrm{M}_{1}+$ peptone at $15 \mathrm{~h}$ after inoculation, showed more antifungal activity than those of the other media (Fig. 2). Biocontrol activity of cells that harvested at $15 \mathrm{~h}$ was better than those of $25 \mathrm{~h}$. Moreover, bacteria obtained from $\mathrm{M}_{1}+2$-ammonium hydrogen phosphate were more effective in increasing the length of roots in both of times but bacteria obtained from $\mathrm{M}_{1}+2$-ammonium hydrogen phosphate at the time of $25 \mathrm{~h}$ improved its effect on the growth factors (Table 4). Bacteria obtained from $\mathrm{M}_{1}+$ urea were like bacteria obtained from $\mathrm{M}_{1}+2$-ammonium hydrogen phosphate that bacteria in the second time
Table 3: Effect of different carbon and nitrogen sources in flask culture on ability of bacteria to improved the growth factors of sunflower

\begin{tabular}{lllll}
\hline Media & $\begin{array}{l}\text { Dry } \\
\text { weight }\end{array}$ & $\begin{array}{l}\text { Wet } \\
\text { weight }\end{array}$ & $\begin{array}{l}\text { Length } \\
\text { of stem }\end{array}$ & $\begin{array}{l}\text { Length } \\
\text { of root }\end{array}$ \\
\hline $\mathrm{M}_{1}$ & $0.24^{\mathrm{c}}$ & $2.68^{\mathrm{c}}$ & $19.33^{\mathrm{bc}}$ & $18.33^{\mathrm{a}}$ \\
$\mathrm{M}_{1}+2$-ammonium & $0.32^{\mathrm{a}}$ & $3.93^{\mathrm{a}}$ & $24.33^{\mathrm{a}}$ & $16.67^{\mathrm{a}}$ \\
hydrogen phosphate & & & & \\
$\mathrm{M}_{1}+$ peptone & $0.27^{\mathrm{bc}}$ & $3.12^{\mathrm{bc}}$ & $21.67^{\mathrm{ab}}$ & $16.67^{\mathrm{a}}$ \\
$\mathrm{M}_{1}+$ urea & $0.3^{\mathrm{ab}}$ & $3.7^{\mathrm{ab}}$ & $42.17^{\mathrm{ab}}$ & $17^{\mathrm{a}}$ \\
$\mathrm{M}_{2}$ & $0.17^{\mathrm{d}}$ & $2.67^{\mathrm{c}}$ & $16^{\mathrm{cd}}$ & $16.67^{\mathrm{a}}$ \\
$\mathrm{M}_{3}$ & $0.23^{\mathrm{c}}$ & $3.2^{\mathrm{bc}}$ & $17^{\mathrm{ad}}$ & $16^{\mathrm{a}}$ \\
control & $0.13^{\mathrm{d}}$ & $1.48^{\mathrm{d}}$ & $13.67^{\mathrm{d}}$ & $11^{\mathrm{b}}$ \\
\hline statistical significance was judged at the $\mathrm{p}<0.01$ & & \\
\end{tabular}

Table 4: Effect of Bacteria obtained from fermentor medium containing: $\mathrm{M}_{1}+2$-ammonium hydrogen phosphate on growth factors of sunflower in two times 15 and $25 \mathrm{~h}$ after inoculation

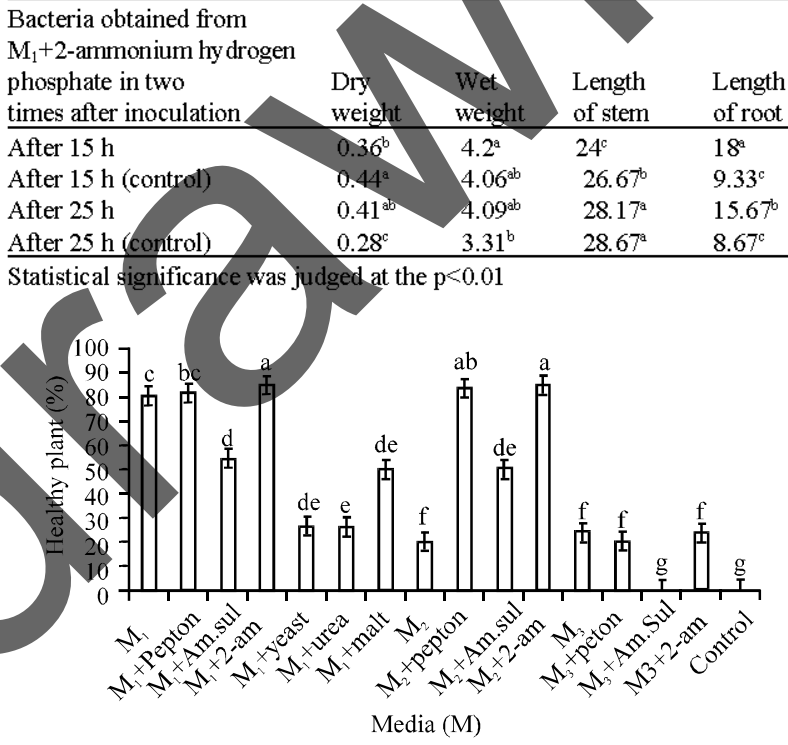

Fig. 1: Biocontrol activity of Pseudomonas fluorescens UTPF61 grown in flask media with different combinations of nitrogen and carbon sources, against Sclerotinia sclerotiorum under greenhouse conditions. Am.sul: Ammonium sulphate, 2-am: 2-ammonium hydrogen phosphate. Percent of healthy plants determined after 30 days. Values followed by the same letter were not significantly different at $5 \%$, as determined by variance analysis followed by Duncan's test

after incubation were more effective than the first time (Table 5) but about bacteria obtained from $\mathrm{M}_{1}+$ peptone harvested bacteria in the time of $15 \mathrm{~h}$ were more effective than the time of $25 \mathrm{~h}$ (Table 6).

Formulation and air-drying: Shelf-life of formulated bacteria obtained from different media was investigated in two temperatures. In all of the treatments, population of UTPF61 decreased in both of temperatures $\left(4\right.$ and $25^{\circ} \mathrm{C}$ ), but the level of reduction was not the same for all 
treatments. The population of cells from $\mathrm{M}_{3}+$ peptone had higher decline whereas the sensitivity of cells from $\mathrm{M}_{1}+2$ ammonium hydrogen phosphate to air drying was lower than those of other treatments. Almost in all treatments

Table 5: Effect of Bacteria obtained from fermentor medium containing: $\mathrm{M}_{1}+$ peptone on growth factors of sunflower in two times 15 and $25 \mathrm{~h}$ after inoculation

Bacteria obtained from

$\mathrm{M}_{1}+2$-ammonium hy drogen

phosphate in two

times after inoculation

After $15 \mathrm{~h}$

After $15 \mathrm{~h}$ (control)

After $25 \mathrm{~h}$

After $25 \mathrm{~h}$ (control)

Statistical significance was judged at the $p<0.01$
UTPF61 survived up to 90 days and in some of them up to 150 days without any dramatic decline from the initial population (Fig. 3, 4).

Table 6: Effect of Bacteria obtained from fermentor medium containing: $\mathrm{M}_{1}+$ urea on growth factors of sunflower in two times 15 and $25 \mathrm{~h}$ after inoculation

Bacteria obtained from

$\mathrm{M}_{1}+2$-ammonium hy drogen

phosphate in two

Dry Wet Length Length

times after inoculation weight weight of stem of root

After $15 \mathrm{~h}$

After $15 \mathrm{~h}$ (control)

After $25 \mathrm{~h}$

$0.32^{\mathrm{ab}}$

$0.32^{\mathrm{b}}$

After $25 \mathrm{~h}$ (control)

$0.3^{\mathrm{ab}}$

$3.51^{\mathrm{a}} \quad 23.33^{\mathrm{bo}} 12.67^{\mathrm{b}}$

$\begin{array}{lll}3.51^{\mathrm{a}} & 23.33^{\mathrm{ab}} & 12.67^{\mathrm{b}} \\ 2.87^{\mathrm{b}} & 23^{\mathrm{ab}} & 11.33^{\mathrm{b}}\end{array}$

$\begin{array}{lll}3.71^{\mathrm{a}} & 23.33^{\mathrm{a}} \quad 14.67^{\mathrm{a}}\end{array}$

Statistical significance was judged at the $p<0.0$

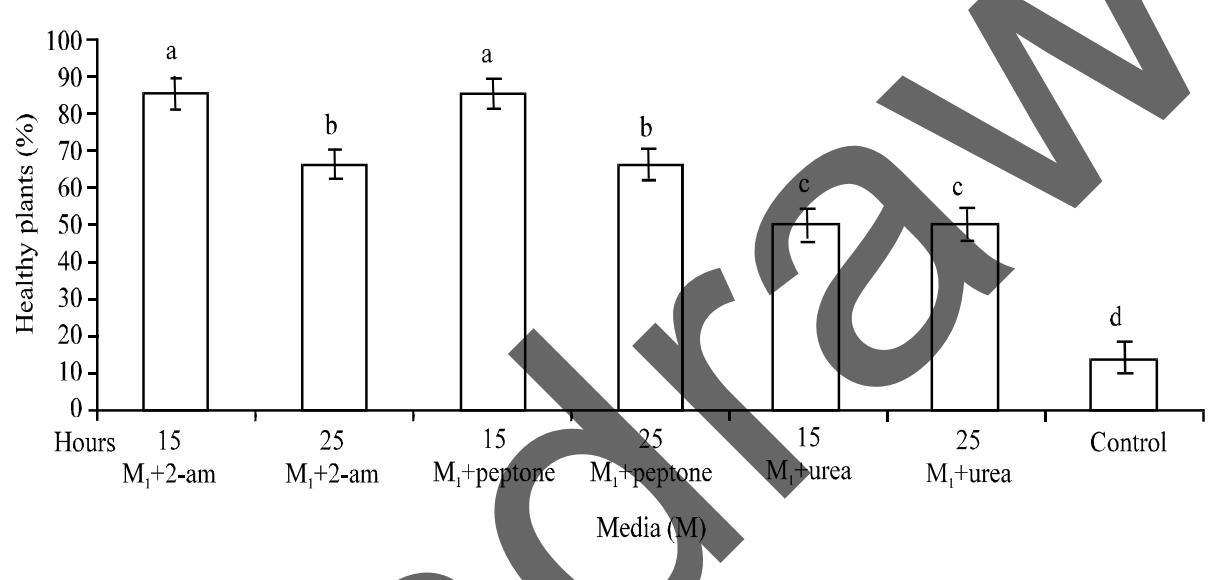

Fig. 2: Biocontrol activity of Pseudomonas fluorescens UTPF61 against Sclerotinia sclerotiorum grown in a fermentor with different of nitrogen sources, against Sclerotinia sclerotionum under greenhouse conditions. $15 \mathrm{~h}: 15 \mathrm{~h}$ after inoculation of bacteria to fermentor 's media, $25 \mathrm{~h} .25 \mathrm{~h}$ after inoculation of bacteria to fermentor's media. Percent of healthy plants determined after 30 days. Values followed by the same letter were not significantly different at $5 \%$, as determined by variance analysis followed by Duncan's test, Am.sul: Ammonium sulphate, 2-am: 2ammonium hydrogen phosphate

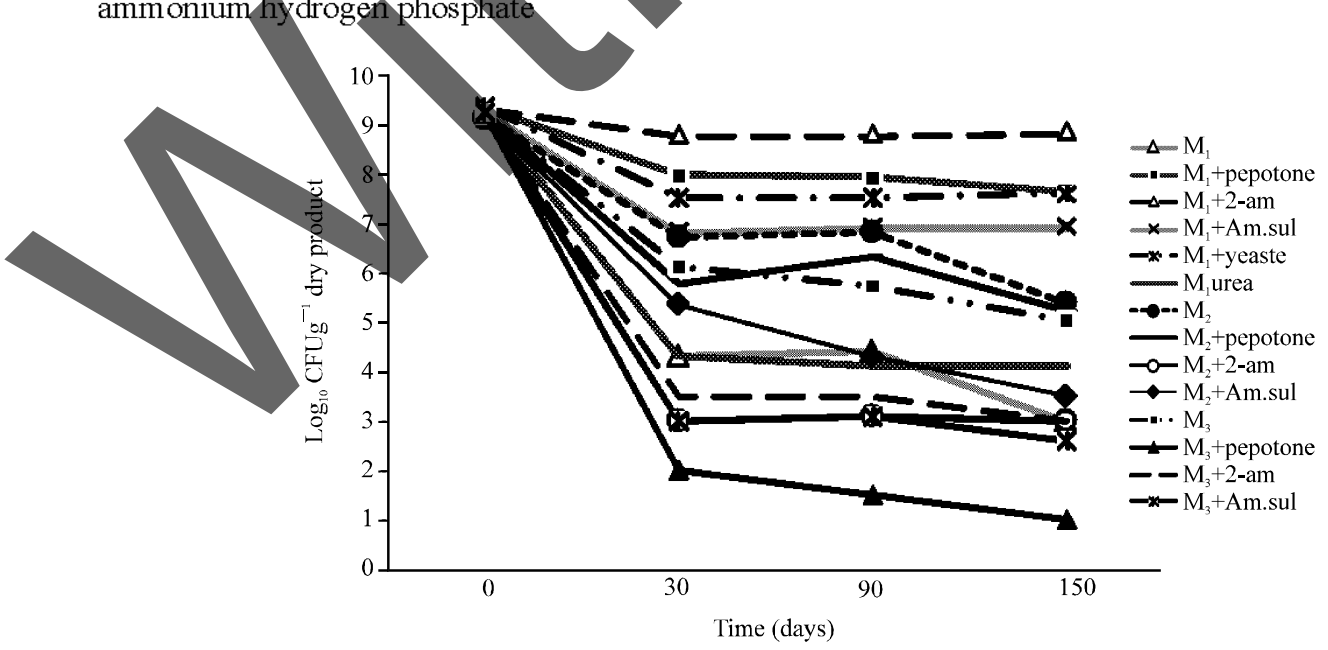

Fig. 3: Survival of Pseudomonas fluorescens UTPF61 grown in culture media with different carbon and nitrogen sources during air drying and maintenance of its talc-based formulation for 150 days in vials at $25^{\circ} \mathrm{C}$, Am.sul: Ammonium sulphate, 2-am: 2-ammonium hydrogen phosphate 
Insight Bacteriology 2 (1): 3-9, 2013

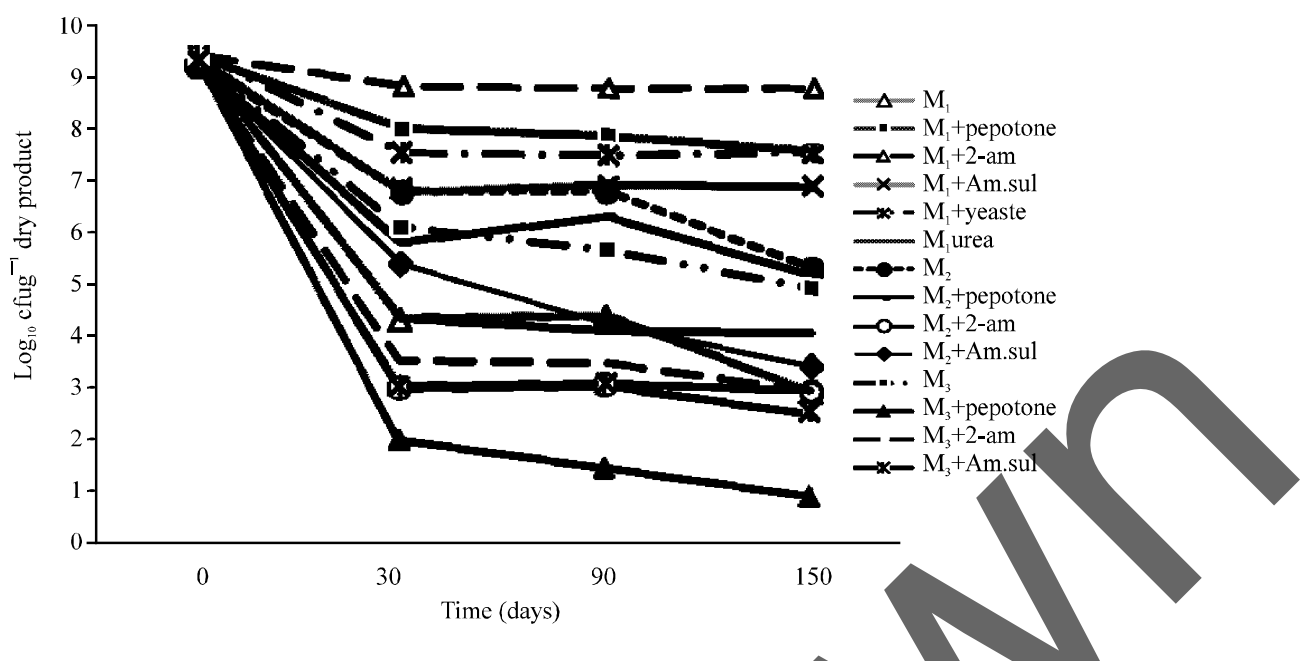

Fig. 4: Survival of Pseudomonas fluorescens UTPF61 grown in media with different carbon and nitrogen sources during air drying and maintenance of its talc-based formulation for 150 days in vials at $4{ }^{\circ} \mathrm{C}, \mathrm{Arp}$.sul: Ammonium sulphate, 2-am: 2-ammonium hydrogen phosphate

\section{DISCUSSION}

Since the commercial production of $P$. fluorescens for application as a biocontrol agent requires both low cost and high cell density, so the finding the best nutritionat supplements and environmental conditions is important for mass production of this agent.

The results obtained in this study showed that the nature of carbon and nitrogen sources in culture media influences the rate of bacterial growth but notably the medium showing more effect on the bacterial growth, had not more effect on protective activity, in other word, no correlation was found between the rate of bacterial growth and antagonistic efficacy. This is in common with the findings by Duffy and Defago (2000) and Costa et al. (2001).

Moreover, according to the flask culture studies, maximum of growth observed in $\mathrm{M}_{1}+2$-ammunium hydrogen phosphate and there wasn't significant difference between two harvesting times. But the amazing results happened about $\mathrm{M}_{1}+$ urea and $\mathrm{M}_{1}+$ peptone that unlike to the previous experiments in flask there wasn't any significant difference in both of the times between these two media from the rate of growth. In general in this study in one $\mathrm{ml}$ of cultivation media the concentration of bacterium is more than one $\mathrm{ml}$ of media in the experiments on flasks.

There are reports that medium and conditions used for production of biocontrol agents, influence their ability to survive during the formulation process (Slininger et al., 1996; Zhang et al., 2005). For example mild thermal and $\mathrm{pH}$ stresses and carbon starvation can increase the resistance of cells to further stresses (Van Overbeek et al.,
1995, Givskor et al., 1994a, b; Jenkins et al., 1988; Qestling et al., 1993). There are different hypotheses to explain these phenomena. In most of these studies resistance of cells was the result of expression of shockinducible proteins like heat and cold shock proteins. In our study bacterial populations that were grown in medium with a combination of $\mathrm{M}_{1}+2$-ammonium hydrogen phosphate has a lowest decrease after formulation. Perhaps this combination of carbon and nitrogen stimulated expression of stress-tolerance proteins.

\section{ACKNOWLEDGMENT}

This study was partially supported by research Grant from the Biological Control Research Center of the Tehran University which we gratefully acknowledge.

\section{REFERENCES}

Adams, T.T., M.A. Eiteman and B.M. Hanel, 2002. Solid state fermentation of broiler litter for production of biocontrol agents. Bioresour. Technol., 82: 33-41.

Agrios, N.G., 2005. Plant Pathology. 5th Edn., Elsevier Academic Press, New York.

Ali, S., Ikram-ul-Haq, M.A. Qadeer and J. Iqbal, 2002. Production of citric acid by Aspergillus niger using cane molasses in a stirred fermentor. Elect. J. Biotechnol., Vol. 5,

Costa, E., N. Teixdo, J. Usall, E. Atares and I. Vinas, 2001. Production of the biocontrol agent Pantoea agglomerans strain CPA-2 using commerical products and by-products. Applied Microbiol. Biotecnol., 56: $367-371$ 
Defago, G., C.H. Berling, U. Burger, D. Hass and G. Kahr et al., 1990. Suppression of Black Root Rot of Tobacco and other Root Diseases by Strains of Pseudomonas fluoresens: Potential Applications and Mechanisms. In: Biological Control of Soil-Borne Plant Pathogens, Hornby, D., R.J. Cook (Eds.). CAB International, Wallingford, UK.

Duffy, B.K. and G. Defago, 1999. Environmental factors modulating antibiotic and siderophore biosynthesis by Pseudomonas fluorescens biocontrol strains. Applied Environ. Microbiol., 65: 2429-2438.

Duffy, B.K. and G. Defago, 2000. Controlling instability in gacS-gacA regulatory Genes during inoculants production of Pseudomonas fluorescens biocontrol strains. Applied Environ. Microbiol., 66: 3142-3150.

Expert, J.M. and B. Digat, 1995. Biocontrol of Sclerotinia wilt of sunflower by Pseudomonas putida strains. Can. J. Microbiol., 41: 685-691.

Givskov, M., L. Eberl and S. Molin, 1994a. Responses to nutrient starvation in Pseudomonas putida KT2442: Two-dimensional electrophoretic analysis of starvation- and stress-induced proteins. J. Bacteriol., 176: 4816-4824.

Givskov, M., L. Eberl, S. Muller, L.K. Poulsen and S. Molin, 1994b. Responses to nutrient starvation in Pseudomonas putida KT2442: Analysis of general cross protection, cell shape and macromolecular content. J. Bacteriol., 176: 7-14.

Heidary, T.F., 2008. Study on the effect of some carbon and nitrogen sources on production process of fluorescent pseudomonads for controlling of sunflower sclerotinia rot disease. M.Sc. Thesis, University of Tehran, Karaj, Iran.

Jenkins, D.E., JE. Schhultz and A. Matin, 1988. Starvation-induced cross protection against heat or $\mathrm{H}_{2} \mathrm{O}_{2}$ challenge in Escherichia coli. J. Bacteriol., 170: 3910-3914.

Keel, C., D.M. Weller, A. Natsch, G. Defago, R.J. Cook and L.S. Thomashow, 1996. Conservation of the 2,4-diacetylphloroglucinol biosynthesis locus among fluorescent pseudomonas isolates from diverse geographic locations. Applied Environ. Microbiol., 62: 552-563.

Lam, K.S., D.R. Gustavson, J.M. Veitch, S. Forenza and J. Ross et al., 1994. Large scale production and semipurification of kedarcidin in a $1000-\mathrm{L}$ fermentor. J. Ind. Microbiol., 13: 356-360.
Moeinzadeh, A., F. Sharif-Zadeh, M. Ahmadzadeh and F. Heidari Tajabadi, 2010. Biopriming of sunflower (Helianthus annuus L.) seed with Pseudomonas fluorescens for improvement of seed invigoration and seedling growth. Australian J. Crop Sci., 4: 564-570.

Oestling, J., L. Holmquist, K. Flaerdh, B. Svenblad, A.E. Jouper-Jaan and S. Kjelleberg, 1993. Starvation and Recovery of Vibrio. In: Starvation in Bacteria, Kjelleberg, S. (Ed.). Plenum Press, New York, USA., pp: 103-128.

Schroth, M.N., J.E. Loper and D.C. Hildebrand, 1984. Bacteria as Biocontrol Agents of Plant Disease. In: Current Perspectives in Microbial Ecology, Klug, M.J. and C.A. Reddy (Eds.)., American Society for Microbiology, Washington DC., USA., pp: 362-369.

Slininger, P.J. and M.A. Sheawilbur, 1995. Liquid culture $\mathrm{pH}$, temperature, and carbon (not nitrogen) source regulate phenazine productivity of the take-all biocontrol agent Pseudomonas-2-79. Applied Microbiol Biotechnol., 43: 794-800.

Slininger, P J., J.E. van Cauwenberge, R.J. Bothast, D.M. Weller, L.S. Thomashow and R.J. Cook, 1996. Effect of growth culture physiological state, metabolites and formulation on the viability, phytotoxicity and efficacy of the take-all biocontrol agent Pseudomonas fluorescens 2-79 stored encapsulated on wheat seeds. Applied Microbiol. Biotechnol., 45: 391-398.

an Overbeek, L.S., L. Eberl, M. Givskov, S. Molin and J.D. van Elsas, 1995. Survival of and induced stress resistance in, carbon-starved Pseudomonas fluorescens cells residing in soil. Applied Environ. Microbiol., 61: 4202-4208.

Vidhyasekaran, P. and M. Muthamilan, 1995. Development of formulations of Pseudomonas fluorescens for control of chickpea wilt. Plant Dis., 79: $782-786$.

Weller, D.M., 1988. Biological control of soilborne pathogens in the rhizosfere with bactria. Annu. Rev. Phytopathol., 26: 379-407.

Zhang, S., D.A. Schisler, M.J. Boehm and P.J. Slininger, 2005. Carbon-to-nitrogen ratio and carbon loading of production media influence freeze-drying survival and biocontrol efficacy of Cryptococcus nodaensis $\mathrm{OH}$ 182.9. Phytopathology, 95: 626-631. 